УДК 351.77

DOI: https://doi.org/10.26642/jen-2020-4(94)-160-164

Ю.М. Малігон, здобувач

Державний університет «Житомирська політехніка»

\title{
Державна кадрова політика у сфері охорони здоров'я: теоретичні засади та сучасні тенденції
}

(Представлено: д.держ.упр., дои.. Антонов А.В.)

У статті охарактеризовано теоретичні засади державної кадрової політики та сучасні тенденції ї̈ розвитку. Доведено, щзо кадри відіграють ключову роль у вирішенні проблемних питань розвитку медичної галузі. Виокремлено основні чинники впливу на формування державноі кадрової політики. Визначено, щзо серед невідкладних завдань, щзо стоять перед системою охорони здоров'я в Украӥні, першочергово потребує вдосконалення кадрова політика. 3'ясовано, що кадровий потениіал є найвагомішою складовою ресурсного забезпечення системи охорони здоров'я. Обтрунтовано необхідність професійної підготовки кадрів вищих медичних навчальних закладів в Україні. Доведено, щзо шляхом втручання держави в усі напрями підготовки кадрів для системи охорони здоров'я в перспективі можливі реальні зміни в кількості хворих та відповідно зменшення показника смертності населення й підвищення якості надання медичних послуг. Визначено актуальність підвищення рівня професіоналізму кадрів сфери охорони здоров'я, у тому числі кадрів - представників середнього медичного персоналу у контексті реформування системи охорони здоров'я України. Виявлено, щз стратегічні зміни в механізмі державного управління системи охорони здоров'я є необхідною передумовою побудови країни кардинально нової генерації із здоровим населенням. Окреслено основні напрями, за якими може формуватися державна політика у сфері охорони здоров'я України в подальшій перспективі. Доведено, що перспективність досліджень аналогічної тематики та важливість кардинальних змін висуває на перший план необхідність удосконалення й оновлення державної кадрової політики в системі охорони здоров'я відповідно до новітніх вимог та викликів сучасного світу. Адже головними завданнями розвиненої держави є побудова дієвої моделі системи охорони здоров'я, покращення рівня здоров'я населення та забезпечення розвитку здорової украӥнської нації.

Ключові слова: система охорони здоров'я; кадрове забезпечення медицини; державне регулювання медичних закладів; державна кадрова політика; механізми державного управління.

Актуальність теми. У сучасних українських реаліях основою формування успішного суспільства як ключового напряму суспільно-економічного розвитку є кадровий потенціал. Головна роль при цьому відводиться державному регулятору, що спроможний підвищити конкурентоспроможність фахівця будьякої галузі на ринку праці. Не є виключенням й система охорони здоров'я. У таких умовах перед системою охорони здоров'я постає достатньо серйозне питання забезпечення країни достойними фахівцями, що можуть стати каталізаторами та регуляторами успішних трансформацій у медичній галузі, на що має бути зорієнтована відповідна державна кадрова політика.

Аналіз останніх досліджень та публікацій, на які спирається автор. Дослідження проблем кадрової політики завжди залишається в полі зору як зарубіжних, так і вітчизняних науковців. Серед вітчизняних вчених, зацікавлених у вивченні цієї проблематики, варто виокремити О.А. Грішнову, Е.М. Лібанову, О.В. Макарову, Л.С. Лісогор, С.А. Калашнікову, В.В. Тертичку, О.В. Берданову, В.В. Близнюк, І.М. Новак, Я.І. Юрик та інших.

Метою статті $є$ дослідження сучасного стану та особливостей розвитку кадрового забезпечення сфери охорони здоров'я України 3 метою визначення подальших перспектив його успішного реформування та розвитку в сучасних умовах.

Викладення основного матеріалу. Кадри мають велику вагу в системі взаємодії суспільства й держави та $є$ носієм досвіду. Саме тому державну кадрову політику варто вважати одним із перспективних напрямів державного управління, що відіграє роль оптимізатора трудового потенціалу країни $з$ метою реалізації функцій держави, підвищення конкурентоспроможності окремих регіонів та країни в цілому. Крім того, особливої актуальності сьогодні в умовах розвитку науково-технічного прогресу набувають інтелект, освіченість, творчі здібності індивіда, що стають необхідною передумовою та рушійною силою прогресу.

Відходячи від тоталітарного минулого, Україна сьогодні перебуває у стані трансформаційних перетворень та зміни орієнтирів у сприйнятті реформ соціально-економічної політики. I основою соціально-економічного розвитку України є саме державна кадрова політика. Доктор наук 3 державного управління, професор Ю.Ковбасюк під державною кадровою політикою пропонує розуміти

(C) Ю.М. Малігон, 2020 
цілеспрямовану стратегічну діяльність держави, пов’язану 3 плануванням та прогнозуванням формування, професійного розвитку та раціонального використання кадрів, усіх трудових ресурсів України, визначенням цілей і пріоритетів кадрової діяльності [2, с. 3].

На нашу думку, державна кадрова політика - це багатоступенева система послідовного виконання ряду заходів нормативно-правового, організаційно-управлінського, науково-дослідного та іншого характеру з метою забезпечення розвитку держави та суспільства в цілому.

У 2012 році була розроблена Стратегія державної кадрової політики на 2012-2020 роки, серед головних причин розроблення якої зазначено:

- стримування розвитку та функціонування системи кадрового забезпечення в державі;

- відсутність ефективної системи моніторингу потреб суспільства і держави у фахівцях із відповідним освітньо-кваліфікаційним рівнем підготовки, недосконалість механізму формування державного замовлення на підготовку фахівців;

- відсутність збалансованої системи управління професійною орієнтацією молоді, об'єктивних принципів їі відбору і навчання, повільні темпи впровадження сучасних технологій професійного розвитку;

- недостатнє застосування наукових підходів, результатів наукових досліджень при формуванні та реалізації державної кадрової політики [7].

На думку М.М. Білинської, на формування державної кадрової політики впливає низка системних чинників, які визначають ¥ї особливості та які можна розділити на дві групи: постійні і змінні. До постійних варто зарахувати: історичні, ментальні, територіальні, природно-кліматичні, демографічні, релігійно-конфесійні. До змінних - політичні, науково-технічні, фінансово-економічні [1] (рис. 1).

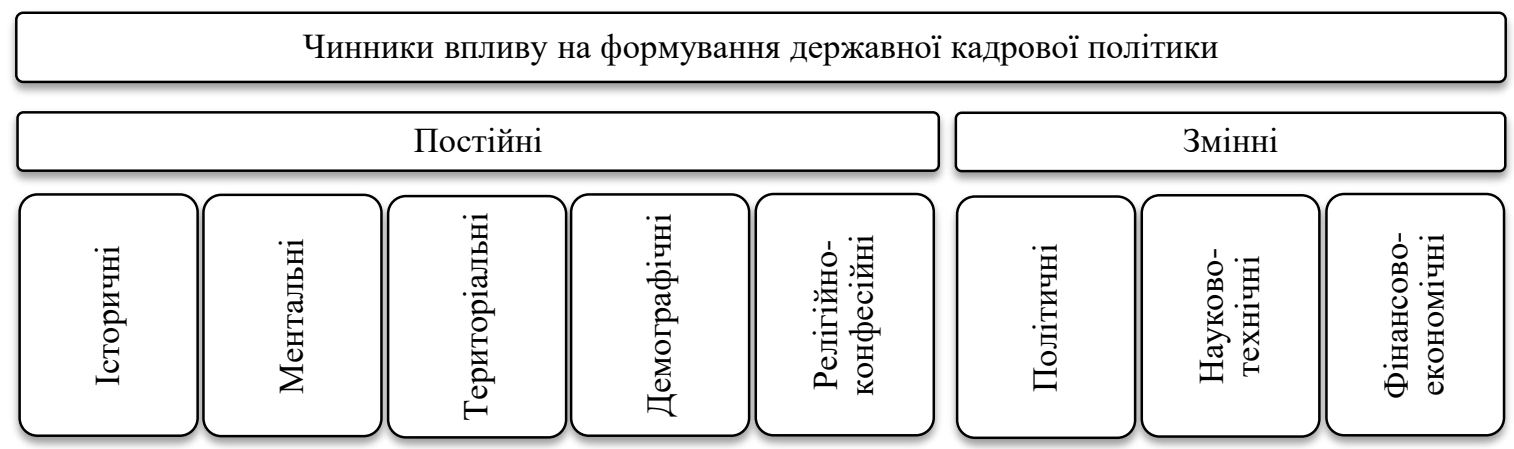

Рис. 1. Чинники впливу на формування державної кадрової політики в Україні на думку М.М. Білинської [1]

Становлення України як держави з соціально орієнтованою економікою, її євроінтеграційні орієнтації передбачають формування та розвиток висококваліфікованих фахівців сфери охорони здоров'я, причому як у самих медичних закладах, так і в органах державної влади - державних службовців, посадових осіб місцевого самоврядування, ефективних практиків та перспективних науковців.

У системі Міністерства охорони здоров'я України на кінець 2018 року зареєстровано 191905 штатних лікарських посад (рис. 2). Показник укомплектованості штатних лікарських посад лікарями (фізичними особами) в цілому становить 81,7 \%, як і в попередньому році. Показник укомплектованості штатних посад лікарями (фізичними особами) в лікувально-профілактичних закладах становить 78,0 \%, у 2017 році- 78,2\%. В окремих типах закладів укомплектованість фізичними особами становить: в обласних лікарнях - 85,7 \%, міських лікарнях - 78,9 \%, ЦРЛ - 75,7 \%, дільничних лікарнях - 72,9 \%; в сільських лікарських амбулаторіях - 67,6 \%. Розрив між штатними лікарськими посадами і фізичними особами становить 35042, кількість посад зайнятих по сумісництву - 11398, коефіцієнт сумісництва - 1,1 [3].

У закладах системи MO3 на лікарських посадах працюють 3,0 тис. осіб 3 вищою немедичною освітою, переважно в лікувально-профілактичних закладах (на посадах лікарів-лаборантів - 2262, лікарів-статистиків - 189, лікарів лікувальної фізкультури - 41) [3].

Численні фундаментальні помилки заважають Україні отримувати вигоду від власного людського капіталу, що в подальшому може негативно сказатися на розвитку галузі через відтік висококваліфікованих медичних кадрів за кордон, що із загостренням коронакризи вже відбувається 3 найближчими сусідами. Польська медична галузь вже сьогодні відчуває нестачу у кваліфікованих медичних кадрах різних рангів від лікарів до середнього та молодшого медичного персоналу. Особливо це стало відчутно у процесі боротьби з COVID-19, тому Польща активно почала запрошувати українські медичні кадри 3 метою подальшого працевлаштування, гарантуючи при цьому істотно вищий рівень оплати праці, гідні соціальні стандарти, місце проживання та можливість подальшого влаштування всіх членів сім’ї. 


\section{Всього лікарів (враховуючи приватних)}

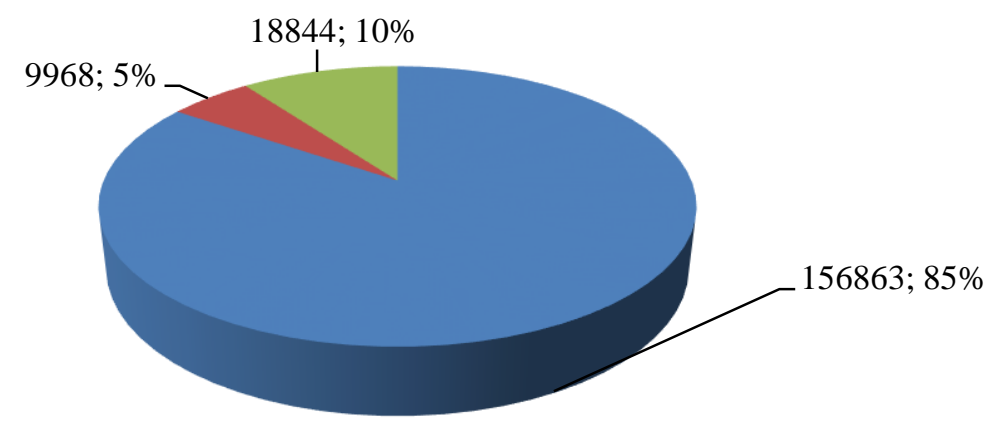

Міністерство охорони здоровя України $\square$ інші міністерства та відомства $\square$ приватні структури

Рис. 2. Медичні кадри відповідно до підвідомчості (станом на 31.12.2018 року)

Українці ж у свою чергу витрачають на охорону здоров'я не малу частку свого доходу. Так, загальні витрати на охорону здоров’я становили близько 7,6 \% від ВВП. Цей показник вищий, ніж аналогічний у деяких країнах-членах Європейського Союзу, як-то Польща, Румунія, Естонія, які забезпечують істотно кращі умови у сфері медицини для своїх громадян і отримують кращі результати ефективності діяльності системи охорони здоров'я в цілому. Через низький рівень ВВП показник витрат на душу населення в Україні становив у 2016 році близько \$250, що значно нижче, ніж у Чехії - близько \$1400, Польщіблизько \$850 і навіть Румунії - близько \$400).

Крім того, Україні характерна величезна невідповідність між тим, що гарантує держава і тим, що вона забезпечує. Нормативно усі верстви населення забезпечені найнеобхіднішою медичною допомогою, яка $є$ безкоштовною в державних та комунальних закладах системи охорони здоров'я України. Насправді ж, громадяни протягом багатьох років зіштовхуються 3 проблемою оплати «з власного гаманця» наданих послуг навіть у державних медичних закладах та не мають відповідного захисту від хабарництва та здирництва у разі хвороби, діагностики та лікування.

Кількісна складова кадрів закладів охорони здоров'я у 1995-2017 роках вказана на рисунку 3, що демонструє тенденції до зменшення як кількості лікарів усіх спеціальностей, так і кількості середнього медичного персоналу із року в рік. Якщо у 1995 році кількість середнього медичного персоналу становила майже 600 тис. осіб, то у 2017 році їх кількість зменшилася майже вдвічі і становила відповідно 360 тис. осіб. Причинами цього насамперед є, на нашу думку, низький рівень оплати праці представників цієї професії, низький рівень модернізації державних медичних закладів, ігнорування потреб населення у кваліфікованих медичних кадрах, неефективна робота системи в цілому та високий рівень корупції галузі.

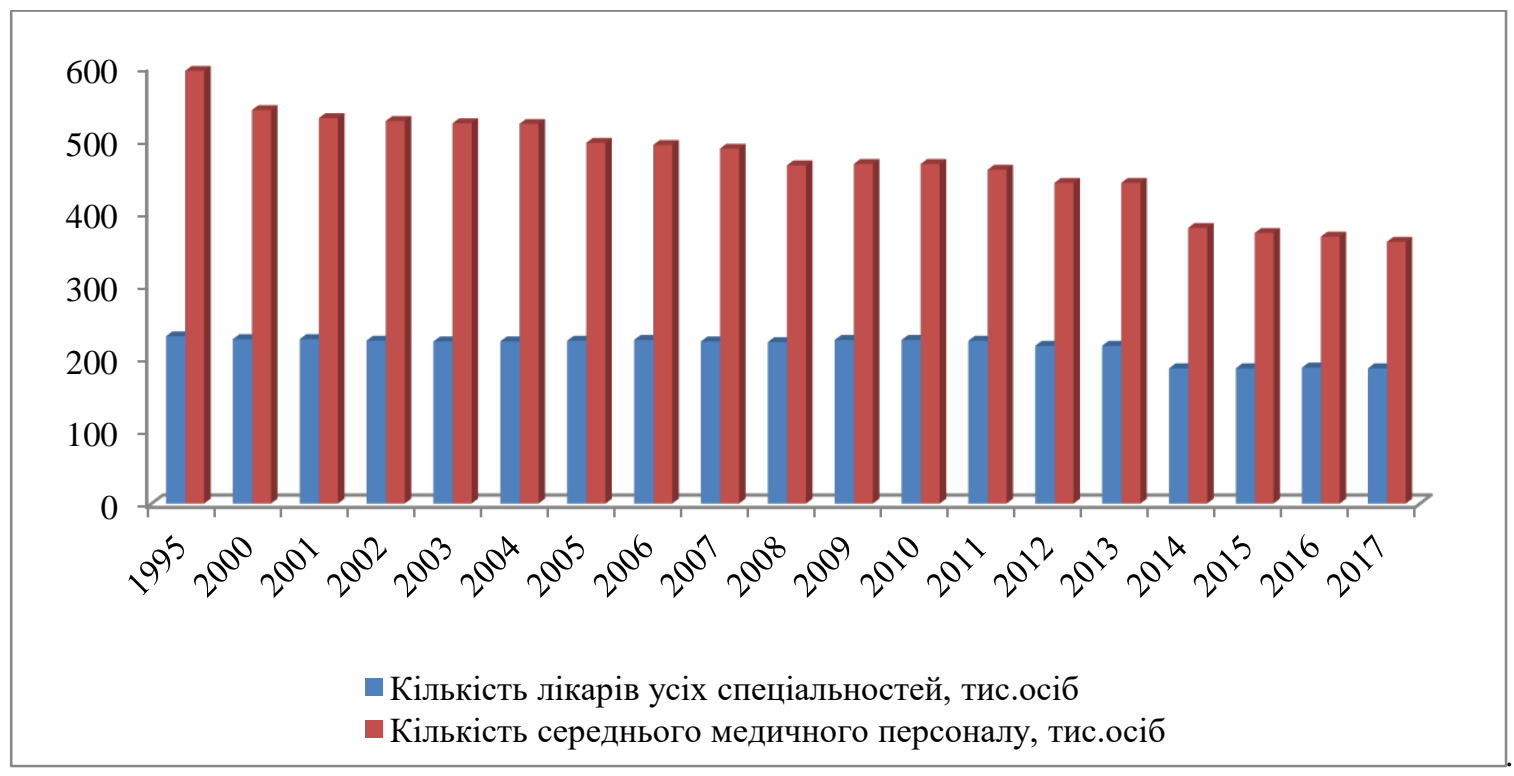

Рис. 3. Кількісна складова кадрів закладів охорони здоров'я у 1995-2017 роках 
Головною передумовою існування результативної державної кадрової політики у сфері охорони здоров’я є побудова професійної державної кадрової служби, що доводитиме престиж професії для висококваліфікованих медичних кадрів, які у своій професійній діяльності будуть керуватися принципами служіння народу та патріотизму та будуть еталоном моралі, честі та професіоналізму.

Окреслимо напрями, за якими може формуватися державна кадрова політика у сфері охорони здоров’я України в подальшій перспективі:

$\checkmark$ формування концепції кадрової політики в сфері охорони здоров'я;

$\checkmark$ створення відповідної нормативно-правової бази забезпечення кадрової політики;

$\checkmark$ створення спеціальних органів боротьби і контролю у цій сфері;

$\checkmark$ оперативне розслідування та постійний моніторинг можливих корупційних проявів у сфері кадрової політики охорони здоров’я України;

$\checkmark$ активне міжнародне співробітництво у напрямі забезпечення кадрової політики;

$\checkmark$ належне фінансування державного апарату кадрової політики у сфері охорони здоров'я;

$\checkmark$ розроблення відповідних професійних стандартів, Національної рамки кваліфікації;

$\checkmark$ підтримка державного фінансування цільових наукових досліджень у сфері розвитку людського потенціалу держави;

$\checkmark$ розроблення дієвих механізмів прогнозування, планування, постійного моніторингу кадрових потреб у медичних кадрах у країні;

$\checkmark$ розроблення ефективного механізму залучення висококваліфікованих фахівців до формування та реалізації державної кадрової політики у сфері охорони здоров'я;

$\checkmark$ державне регулювання програм перепідготовки та навчання медичних кадрів протягом життя;

$\checkmark$ формування кадрів нової генерації з урахуванням науково-технічного та соціального прогресу;

$\checkmark$ розроблення механізму підтвердження кваліфікацій медичних кадрів та дипломів вітчизняних медичних закладів освіти на міжнародному рівні;

$\checkmark$ розроблення програм стимулювання роботодавців до прийому на перше робоче місце молодих фахівців сфери охорони здоров'я;

$\checkmark$ удосконалення системи контролю за працевлаштуванням випускників медичних навчальних закладів усіх рівнів, які навчалися за державним замовленням;

$\checkmark$ розробка та реалізація державних програм щодо забезпечення необхідних умов для створення освітньо-трудового потенціалу України з метою надання доступу обдарованої молоді до нових знань незалежно від їх матеріальних можливостей та місця проживання.

Висновки та перспективи подалыших досліджень. 3 огляду на перспективність досліджень аналогічної тематики та важливість кардинальних змін, вважаємо за необхідне удосконалювати та оновлювати державну кадрову політику в системі охорони здоров'я відповідно до новітніх вимог та викликів сучасного світу, адже головними завданнями розвиненої держави $є$ побудова дієвої моделі системи охорони здоров'я, покращення рівня здоров'я населення та забезпечення розвитку здорової української нації в найближчій перспективі. Ефективність управління в медичній галузі зумовлюється насамперед результатами здійснення відповідними державними органами ряду дій організаційного, правового, фінансово-економічного та інших заходів. Одну 3 основних ролей при цьому відіграє компетентність та професіоналізм кадрів сфери вищої медичної школи, а стратегічні зміни в механізмі державного управління системи охорони здоров’я $€$ необхідною передумовою побудови країни кардинально нової генерації зі здоровим населенням.

\section{Список використаної літератури:}

1. Білинська M.М. Стратегія державної кадрової політики України: цілі та шляхи реалізації : навч.-метод. матеріали / М.М. Білинська, В.М. Сороко, В.О. Чмига. - К. : НАДУ, 2013. - 52 с.

2. Державна кадрова політика в Україні: стан, проблеми та перспективи розвитку : наук. доп./ Ю.В. Ковбасюк, К.О. Ващенко, Ю.П. Сурмін та ін. ; за заг. ред. д.держ.упр., проф. Ю.В. Ковбасюка, д.політ.н., проф. К.О. Ващенка, д.соц.н., проф. Ю.П. Сурміна (кер. проекту). - К. : НАДУ, 2012. - 72 с.

3. Медичні кадри та мережа закладів охорони здоров'я системи МОЗ України за 2017-2018 роки : довідник Державного закладу «Центр медичної статистики МО3 України». - 2019. - 66 с.

4. Леган I. Ринок приватної медицини України: особливості регулювання та напрями розвитку / I.Леган, О.Крикун // Галицький економічний вісник. - 2020. - Т. 64, № 3. - С. 192-197.

5. Леган I.M. Напрями вдосконалення державного регулювання ринку приватної медицини / I.M. Леган, О.Д. Крикун // Вчені записки Таврійського національного університету імені В.І. Вернадського. Серія : Державне управління. - 2020. - Т. 31 (70), № 3. - С. 123-127.

6. Офіційний сайт Державної служби статистики України [Електронний ресурс]. - Режим доступу: http://www.ukrstat.gov.ua/.

7. Стратегія державної кадрової політики на 2012-2020 роки : Указ Президента України від 1 лют. 2012 року № 45/2012 [Електронний ресурс]. - Режим доступу : https://zakon.rada.gov.ua/laws/show/45/2012\#Text. 
8. Урсол Г.М. Приватний сектор системи охорони здоров'я - активний резерв підвищення доступності та якості надання медичної допомоги: досвід Кіровоградської області / Г.М. Урсол, О.А. Скрипник, О.М. Василенко // Буковинський медичний вісник. - 2014. - Т. 18, № 4 (72). - С. 177-181.

9. Шпак Г.В. Аналіз забезпечення галузі охорони здоров'я лікарями / Г.В. Шпак, I.I. Волинкін // Україна. Здоров’я нації. - 2011. - № 2 (18). - С. 121-125.

\section{References:}

1. Bilyns'ka, M.M., Soroko, V.M. and Chmyga, V.O. (2013), Strategija derzhavnoi' kadrovoi' polityky Ukrai'ny: cili ta shljahy realizacii', navch.-metod. materialy, NADU, K., 52 p.

2. Kovbasjuk, Ju.V, Vashhenko, K.O., Surmin, Ju.P. et al. (2012), Derzhavna kadrova polityka v Ukrai'ni: stan, problemy ta perspektyvy rozvytku, nauk. dop., in D.Sc., prof. Kovbasjuk, Ju.V., D.Sc., prof. Vashhenko, K.O. and D.Sc., prof. Surmin, Ju.P. (ker. proektu) (ed.), NADU, K., 72 p.

3. Medychni kadry ta merezha zakladiv ohorony zdorov'ja systemy MOZ Ukrai'ny za 2017-2018 roky (2019), dovidnyk, Derzhavnyj zaklad «Centr medychnoi' statystyky MOZ Ukrai'ny», 66 p.

4. Legan, I. and Krykun, O. (2020), «Rynok pryvatnoi' medycyny Ukrai'ny: osoblyvosti reguljuvannja ta naprjamy rozvytku», Galyc'kyj ekonomichnyj visnyk, Vol. 64, No. 3, pp. 192-197.

5. Legan, I.M. and Krykun, O.D. (2020), «Naprjamy vdoskonalennja derzhavnogo reguljuvannja rynku pryvatnoi' medycyny», Vcheni zapysky Tavrijs'kogo nacional'nogo universytetu imeni V.I. Vernads'kogo, Serija Derzhavne upravlinnja, Vol. 31 (70), No. 3, pp. 123-127.

6. Oficijnyj sajt Derzhavnoi' sluzhby statystyky Ukrai'ny, [Online], available at: http://www.ukrstat.gov.ua/

7. Prezydent Ukrai'ny (2012), Strategija derzhavnoi' kadrovoi' polityky na 2012-2020 roky, Ukaz vid 1 ljut. 2012 roku No. 45/2012, [Online], available at: https://zakon.rada.gov.ua/laws/show/45/2012\#Text

8. Ursol, G.M., Skrypnyk, O.A. and Vasylenko, O.M. (2014), «Pryvatnyj sektor systemy ohorony zdorov'ja aktyvnyj rezerv pidvyshhennja dostupnosti ta jakosti nadannja medychnoi' dopomogy: dosvid Kirovograds'koi' oblasti», Bukovyns'kyj medychnyj visnyk, Vol. 18, No. 4 (72), pp. 177-181.

9. Shpak, G.V. and Volynkin, I.I. (2011), «Analiz zabezpechennja galuzi ohorony zdorov'ja likarjamy», Ukrai'na. Zdorov'ja nacii'. No. 2 (18), pp. 121-125.

Малігон Юлія Михайлівна - здобувач кафедри економічної безпеки, публічного управління та адміністрування Державного університету «Житомирська політехніка».

Наукові інтереси:

- $\quad$ кадрова політика у сфері охорони здоров'я;

- державне управління у сфері охорони здоров'я;

- державний механізм кадрового забезпечення системи охорони здоров'я.

Стаття надійшла до редакції 01.10.2020. 